\title{
Czy nie-HDL cholesterol lepiej niż cholesterol frakcji LDL odzwierciedla ryzyko sercowo-naczyniowe?
}

\section{Non-HDL-cholesterol: better than LDL-cholesterol in reflecting cardiovascular risk?}

\author{
Grażyna Sygitowicz ${ }^{1}$, Krzysztof J. Filipiak $^{2}$, Dariusz Sitkiewicz ${ }^{1}$ \\ ${ }^{1}$ Zakład Chemii Klinicznej i Diagnostyki Laboratoryjnej Warszawskiego Uniwersytetu Medycznego \\ ${ }^{2}$ I Katedra i Klinika Kardiologii Warszawskiego Uniwersytetu Medycznego
}

\section{Streszczenie}

W leczeniu zaburzeń lipidowych zasadnicze znaczenie ma stężenie lipidów i lipoprotein osocza. Rutynowy panel lipidowy obejmuje: cholesterol całkowity, triglicerydy, cholesterol frakcji lipoprotein o niskiej gęstości (LDL-C) oraz cholesterol frakcji lipoprotein o wysokiej gęstości (HDL-C). W najnowszych wytycznych Europejskiego Towarzystwa Kardiologicznego (obowiązujące do 2020 r.) wskazano, że oprócz licznych parametrów na arenie lipidowej (apolipoproteiny, stężenie i wielkość cząstek LDL) niezwykle istotny jest kolejny parametr - cholesterol nie-HDL. Ten łatwo dostępny do rutynowego zastosowania klinicznego parametr wyróżniono jako kluczowy drugorzędowyy cel terapii u pacjentów obciążonych ryzykiem kardiometabolicznym.

Cholesterol nie-HDL (nie-HDL-C) jest lepszym parametrem niż LDL-C, szczególnie gdy jest wyliczany zgodnie ze wzorem Friedewalda w przewidywaniu zdarzeń sercowo-naczyniowych, ponieważ nie-HDL-C jest zintegrowanym kompleksem wszystkich cząstek lipoprotein zawierających apolipoproteinę B, czyli: LDL, VLDL, IDL, chylomikrony, remnanty oraz lipoproteinę (a). Można go obliczyć bezpośrednio z wartości rutynowych paneli lipidowych bez dodatkowych kosztów. W opinii autorów nie-HDL-C powinien być prezentowany we wszystkich rutynowych profilach lipidowych wykonywanych w medycznych laboratoriach diagnostycznych. Zaproponowano również nową prezentację wyników rutynowego panelu lipidowego, która pozwala na istotną zmianę celów leczenia, biorąc pod uwagę hierarchię wartości stężeń poszczególnych frakcji lipoprotein i sposób ich interpretacji w zarządzaniu dyslipidemią w celu optymalnego zapobiegania miażdżycy i chorobom układu sercowo-naczyniowego.

Słowa kluczowe: cholesterol nie-HDL, LDL-C, rutynowy panel lipidowy

Folia Cardiologica 2018; 13, 5: 435-441

\section{Wstęp}

Miażdżyca jest kompleksowym procesem, w którym współdziała wiele czynników, takich jak zapalenie, nadciśnienie tętnicze, dyslipidemia, wiek, otyłość, cukrzyca, zła dieta, siedzący tryb życia, nikotynizm [1]. Czynniki te indukują zaburzenia układów: immunologicznego, neurohormonalnego, krzepnięcia, a także dysfunkcję śródbłonka naczyniowego.
Przeprowadzone badania i odkrycia dokonane w ostatnich kilku dziesięcioleciach pozwoliły na poznanie roli metabolizmu lipoprotein w patogenezie choroby niedokrwiennej serca [2]. Na początku zajęto się cholesterolem całkowitym (TC, total cholesterol), do którego przylgnęło miano „złego”, zawartego we frakcji lipoprotein o niskiej gęstości (LDL-C, low-density lipoprotein cholesterol), oraz „dobrego" cholesterolu zawartego we frakcji lipoprotein o wysokiej gęstości (HDL-C, high-density lipoprotein

Adres do korespondencji: dr hab. n. med. Grażyna Sygitowicz, Zakład Chemii Klinicznej i Diagnostyki Laboratoryjnej, Warszawski Uniwersytet Medyczny, ul. Banacha 1, 02-097 Warszawa, e-mail: gsygitowicz@poczta.onet.pl 
cholesterol). Panel lipidowy uzupełniony o stężenie triglicerydów (TG, triglicerydes) do dziś jest podstawą oceny ryzyka sercowo-naczyniowego i na jego podstawie podejmuje się decyzje kliniczne [3].

Postęp wiedzy nie przekłada się jednak na praktykę kliniczną i laboratoryjną. Takie parametry, jak wielkość cząstek lipoprotein, ich liczba, a także stężenie, pozostają jedynie przedmiotem badań i nadal brakuje dowodów na ich znaczenie kliniczne oraz zastosowanie w postępowaniu z pacjentami. Wydaje się, że w przeciwieństwie do wymienionych parametrów lipidowych cholesterol nie-HDL (nie-HDL-C) osiągnął już status ważnego parametru określającego ryzyko sercowo-naczyniowe. Świadczy o tym uwzględnienie go w najnowszych wytycznych Europejskiego Towarzystwa Kardiologicznego (ESC, European Society of Cardiology) jako drugorzędowego celu leczenia [4, 5].

\section{Metabolizm lipoprotein}

Podstawowymi miejscami, w których powstają cząstki HDL, są wątroba i jelito (ryc. 1 - niebieskie strzałki), dzięki którym cholesterol jest transferowany do cząstek apolipoproteiny $\mathrm{Al}$ (ApoAl) lub nascent-HDL ( $\mathrm{nHDL}$ ) i następnie estryfikowany przez osoczowy enzym acylotransferazę lecytyna:cholesterol (LCAT, lecithin-cholesterol acyltransferase). Estry cholesterolu są transportowane do tkanek w celu utrzymania integralności błon komórkowych, generacji energii i metabolizmu do nowych aktywnych biologicznie cząsteczek (hormonów steroidowych). Zwrotny transport cholesterolu jest procesem, w którym cholesterol jest usuwany przez kasetowy transporter wiążący ATP-A1 (ABCA1, ATP binding cassette transporter A1). To niezwykle ważny proces dla usuwania cholesterolu z wypełnionych lipidami makrofagów w ścianie naczyniowej. Nadmiar cholesterolu jest ponownie transportowany do wątroby w celu syntezy kwasów żółciowych, a następnie wydalany z kałem dwoma szlakami (ryc. 1 - czerwone strzałki). Pierwszy z nich, katalizowany przez osoczowe białko transferowe estrów cholesterolu (CETP, cholesterol ester transfer protein), przenosi estry cholesterolu frakcji HDL (high-density lipoprotein) do lipoprotein zawierających apolipoproteinę $B$ (ApoB), czyli IDL (intermediate-density lipoprotein), wymieniając je z triglicerydami.

Cząstki zawierające ApoB są wychwytywane przez wątrobę za pośrednictwem receptorów LDL, a także innych błonowych receptorów (receptor lipoproteiny o bardzo niskiej gęstości [VLDL, very low-density lipoprotein], receptor apolipoproteiny $\mathrm{E}$ (ApoE). Drugi szlak to transport dużych cząstek HDL do hepatocytów za pośrednictwem receptora zmiatającego B1 (SR-B1, scavenger receptor B1).

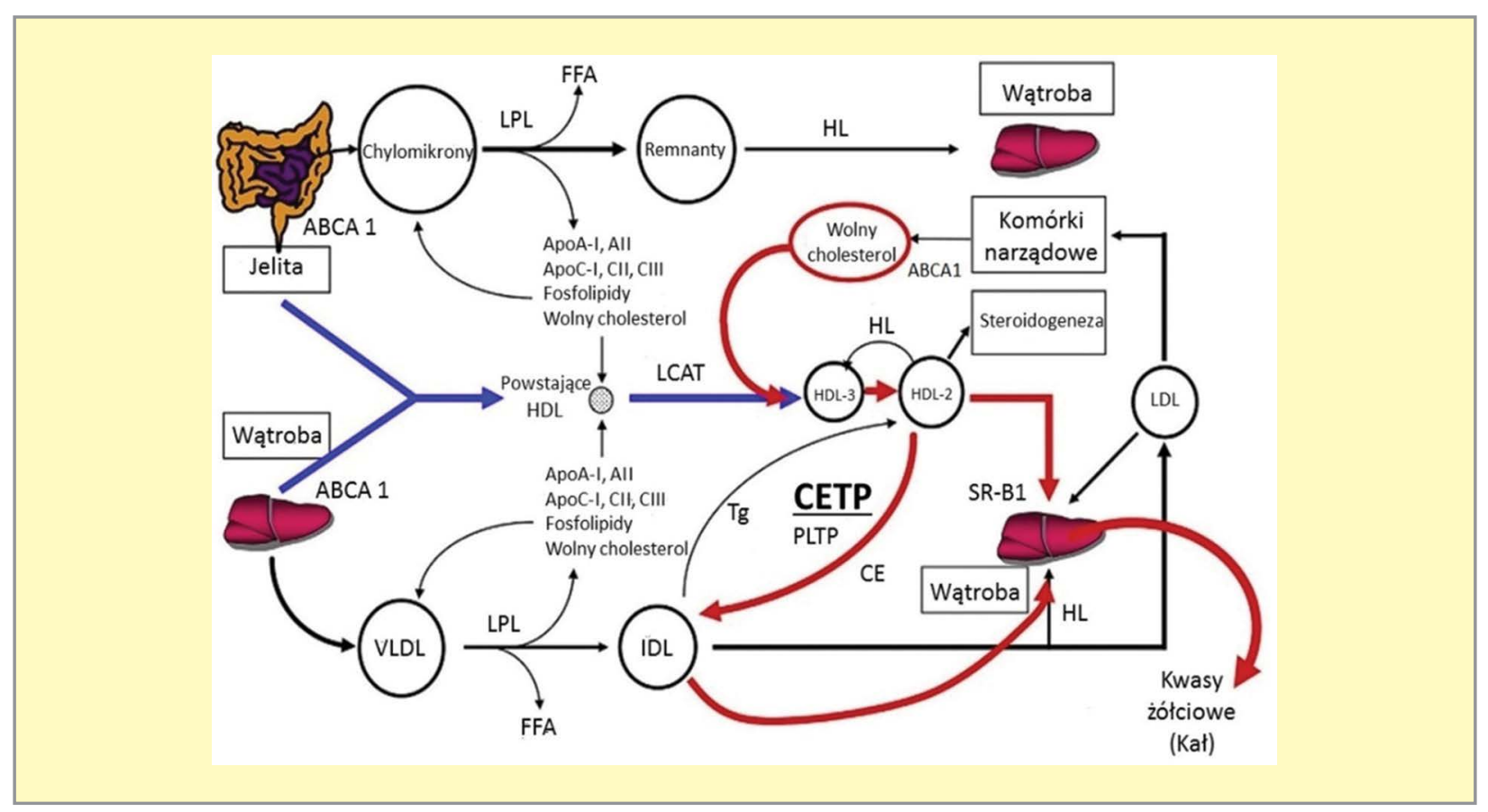

Rycina 1. Schemat metabolizmu lipoprotein; ABCA1 (ATP binding cassette transporter A1) - kasetowy transporter wiążący ATP-A1; Apo - apolipoproteina; CE - cholesterol estryfikowany; CETP (cholesterol ester transfer protein) - osoczowe białko transferowe estrów cholesterolu; FFA (free fatty acids) - wolne kwasy tłuszczowe; HL (hepatic lipase) - lipaza wątrobowa; IDL (intermediate-density lipoprotein) - lipoproteiny o pośredniej gęstości; HDL (high-density lipoprotein) - lipoproteiny o wysokiej gęstości; LCAT (lecithin-cholesterol acyltransferase) - acylotransferaza lecytyna:cholesterol; LDL (low-density lipoprotein) - lipoproteiny o niskiej gęstości; LPL (lipoprotein lipase) - lipaza lipoproteinowa; PLTP (phospholipid transfer protein) - białko transferowe fosfolipidów; SR-B1 (scavenger receptor B1) receptor zmiatają-cy B1; TG (triglicerides) - triglicerydy; VLDL (very low-density lipoprotein) - lipoproteiny o bardzo niskiej gęstości 
Lipoproteiny różnią się nie tyko zawartością apolipoprotein, ale także stężeniami triglicerydów. Nawet w obrębie jednej klasy lipoprotein stężenia cholesterolu i TG są zróżnicowane, co wpływa na ich rozmiar i funkcję. Cząstki LDL uważa się za główne determinanty miażdżycy, szczególnie małe, gęste LDL, które efektywniej transportują cholesterol do wnętrza ściany naczyniowej i są wrażliwsze na oksydacyjną modyfikacje (tworzenie oksydowanych LDL [ox-LDL]). Ostatnio, metodą elektroforezy, wykazano obecność w surowicy pacjentów z dyslipidemią wybitnie elektronegatywnych frakcji LDL (L5) [6]. Frakcje te różnią się od ox-LDL, ale - podobnie jak one - są zdolne do interakcji z receptorem ox-LDL (LOX-1). Zwiększone poziomy aterogennych LDL (ox-LDL i/lub L5) indukują w komórkach śródbłonka ekspresję białka C-reaktywnego (CRP, C-reactive protein), który promuje ekspresję LOX-1 i w efekcie zwiększa transport LDL do komórek, powodując dysfunkcję śródbłonka i nasilenie procesu aterogenezy [7].

Lipoproteiny o wysokiej gęstości (HDL) stanowią heterogenną klasę lipoprotein różniących się składem, rozmiarem, kształtem i gęstością. W ostatnich badaniach proteomicznych zidentyfikowano w HDL więcej niż 50 różnych białek. Skład lipidowy HDL jest także w znacznym stopniu heterogenny. Wzrost stężenia dużych $\alpha$-mobilnych cząstek HDL wiąże się z prawidłowym dojrzewaniem HDL i obniżeniem ryzyka sercowo-naczyniowego. Wysokie stężenia $\alpha_{1}$ HDL są markerem protekcji przed chorobami serca. Wzrost stężeń małych cząstek HDL świadczy o nieprawidłowym dojrzewaniu HDL i wzroście ryzyka choroby niedokrwiennej serca. Wysokie stężenia bardzo małych pre $\beta_{1}$, małych $\alpha_{3}$ i $\alpha_{4}$ cząstek HDL są markerami wysokiego ryzyka klinicznie jawnych i subklinicznych postaci chorób układu sercowo-naczyniowego [8].

Stan zapalny prowadzi do istotnych modyfikacji cząstek HDL, co skutkuje utratą ich ochronnych właściwości [9]. Czynnikiem indukującym powstawanie dysfunkcjonalnych cząstek HDL jest enzym mieloperoksydaza (MPO, myeloperoxidase). Katalizuje ona modyfikację ApoAI w HDL, czyniąc ją niezdolną do aktywacji transportera $A B C A 1-$ w efekcie hamuje zależny od ABCA1 transport zwrotny cholesterolu z makrofagów [10]. Jednocześnie zapalna modyfikacja HDL prowadzi z jednej strony do pozbawienia tych cząstek ważnych enzymów, takich jak peroksydaza glutationowa i paraoksonaza, z drugiej zaś do zmiany stosunku ApoAl do aApoAll i obecności białek ostrej fazy - surowiczego amyIoidu A oraz ceruloplazminy. Efektem tych modyfikacji są: zwiększenie stresu oksydacyjnego, zmniejszenie ekspresji śródbłonkowej syntazy tlenku azotu, zwiększenie apoptozy, a przede wszystkim - utrata zdolności ochronnych przed oksydacyjną modyfikacją LDL. Warto dodać, że procesy te nie przekładają się w żaden sposób na ogólne stężenie HDL oznaczane w codziennej praktyce laboratoryjnej. Oznacza to, że te same wysokie stężenia HDL-C mogą stanowić u jednej osoby „dobry” cholesterol, a u innej osoby nawet zwiększać ryzyko sercowo-naczyniowe. Tłumaczy to opisywany wielokrotnie „paradoks HDL” w praktyce klinicznej polegający na braku u części osób obserwowanych efektów protekcyjnych wysokich stężeń cholesterolu tej frakcji [11]. Przyczyniło się to do pomniejszenia roli oznaczania stężeń HDL-C w obowiązujących wytycznych kardiologicznych. Obecnie nie rekomenduje się żadnych docelowych stężeń tej frakcji lipidowej.

Wzrost stężenia TG w cząstkach lipoprotein czyni je istotnymi determinantami miażdżycy. Lipoproteiny o bardzo niskiej gęstości są aterogenną, bogatą w TG frakcją zawierającą ApoB. Są one syntetyzowane w następstwie transportu do wątroby wolnych kwasów tłuszczowych. Lipoproteiny o bardzo niskiej gęstości stanowią podstawowy nośnik osoczowych triglicerydów i dlatego ich stężenie można traktować jako pośredni wskaźnik stężenia VLDL. Lipaza lipoproteinowa rozkłada VLDL do IDL. Stężenie subfrakcji IDL wzrasta więc w obecności wysokich stężeń TG. Mniejsze cząstki VLDL i cząstki IDL, a także remnanty i chylomikrony mogą również wnikać do ściany naczyniowej, podobnie jak cząstki LDL.

\section{Dlaczego nie-HDL-C wydaje się lepszym markerem ryzyka niż LDL-C?}

Cholesterol nie-HDL stanowi zintegrowany pomiar stężeń wszystkich lipoprotein, które według obecnej wiedzy są związane z inicjacją i progresją miażdżycy [12]. Są to cząstki zawierające ApoB: LDL, VLDL, IDL, chylomikrony, remnanty i Lp(a) (ryc. 2).

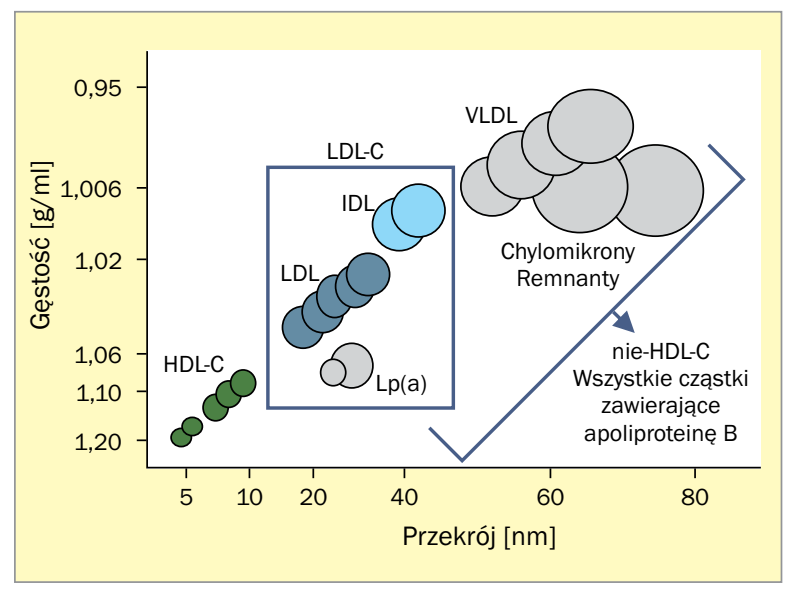

Rycina 2. Wielkość i gęstość lipoprotein; IDL (intermediate-density lipoprotein) - lipoproteiny o pośredniej gęstości; HDL-C (high-density lipoprotein cholesterol) - cholesterol frakcji lipoprotein o wysokiej gęstości; LDL (low-density lipoprotein) - lipoproteiny o niskiej gęstości; LDL-C (low-density lipoprotein cholesterol) cholesterol frakcji lipoprotein o niskiej gęstości; VLDL (very low-density lipoprotein) - lipoproteiny o bardzo niskiej gęstości; nie-HDL-C - cholesterol nie-HDL 
Znaczenie sumy cząstek lipoprotein bogatych w TG zawartych w nie-HDL-C wzrasta z wiekiem populacji, w której częściej występują otyłość, insulinooporność oraz hiperglikemia. Insulinooporność wiąże się ze znacznie większym transportem kwasów tłuszczowych do wątroby, a zatem również ze wzrostem syntezy VLDL. Wartość cholesterolu nie-HDL jest podwyższona szczególnie u pacjentów z zespołem metabolicznym i cukrzycą typu $2[13,14]$.

Dodatkową zaletą nie-HDL-C w porównaniu z LDL-C jest to, że wynik nie zależy od tego, czy pacjent jest na czczo, czy też po posiłku [15]. Rutynowy wynik stężenia LDL-C jest obarczony poważnym błędem w sytuacji pobrania materiału od pacjenta po posiłku. Wynika to z faktu, że w wielu laboratoriach stężenie LDL-C wylicza ze wzoru Friedewalda:

$$
\begin{gathered}
\mathrm{TC}-\mathrm{HDL}-\mathrm{C}-\mathrm{TG} / 5=\mathrm{LDL}-\mathrm{C} \\
\text { jako wynik wyrażony w mg/dl. }
\end{gathered}
$$

Wyliczane stężenie LDL-C jest zafałszowane w przypadkach podwyższonych stężeń TG, poczynając od nawet stosunkowo niskich stężeń (100 mg/dl) aż do zdecydowanych różnic w przypadku stężeń TG powyżej 200 mg/dl [16]. Warto wspomnieć, że niewielką lub umiarkowaną hipertriglicerydemię obserwuje się u pacjentów z zespołem metabolicznym i cukrzycą.

Z czysto laboratoryjnego punktu widzenia wyliczenie nie-HDL-C jest zdecydowanie pewniejsze w porównaniu z LDL-C. Wartość nie-HDL-C jest oparta przede wszystkim na oznaczeniu stężenia TC, które jest dobrze wystandaryzowane i dobrze zwalidowane. Jednocześnie stężenie TC wykazuje znacznie mniejsze zróżnicowanie zarówno biologiczne, jak i laboratoryjne. Należy jednak pamiętać, że stężenie nie-HDL-C zależy także od oznaczanego stężenia HDL-C, które również podlega zróżnicowaniu biologicznemu i zmienności analitycznej. Biologiczne zróżnicowanie HDL-C jest jednak znacznie mniejsze niż innych parametrów lipidowych, w tym przede wszystkim TG. Ponadto stężenia HDL-C są znacznie niższe od stężeń TC, co minimalizuje ich wpływ na zmiany wyliczanego nie-HDL-C.

Niezaprzeczalną zaletą nie-HDL-C jest również to, że można go wyliczyć na podstawie rutynowo oznaczanych parametrów lipidowych. Mimo że stężenie ApoB wydaje się nieco lepszym wskaźnikiem ryzyka chorób układu sercowo-naczyniowego niż wartość nie-HDL-C, to jednak wymaga dodatkowego kosztownego oznaczenia $[17,18]$.

\section{Obecne miejsce stężenia nie-HDL-C w zaleceniach europejskich i polskich kardiologów}

Europejskie Towarzystwo Kardiologiczne, a w ślad za nim Polskie Towarzystwo Kardiologiczne (PTK), szczególnie doceniają obecnie nie-HDL-C jako parametr oceny lipidogramu pacjenta. W dostępnych wytycznych podkreśla się, że ocena
nie-HDL-C jest bardzo prosta i szczególnie istotna u chorych z hipertriglicerydemią związaną z cukrzycą, zespołem metabolicznym, otyłością brzuszną czy przewlekłą chorobą nerek. W 2016 roku ESC doceniło stężenie nie-HDL-C, uznając je w najnowszych wytycznych terapii dyslipidemii - które będą obowiązywały co najmniej do 2020 roku - za jedyny cel drugorzędowy leczenia (cel pierwszorzędowy to nadal obniżanie stężenia LDL-C).

Wartości docelowe nie-HDL-C powinny być co do zasady o $30 \mathrm{mg} / \mathrm{dl}$ wyższe niż odpowiadające im wartości docelowe LDL-C, odpowiada to zatem stężeniu LDL-C powiększonemu o frakcję cholesterolu zawartą w 150 mg/dl TG, czyli górnej granicy zalecanych wartości tej ostatniej frakcji lipidowej. W wytycznych zalecono zatem uzyskanie wartości nie-HDL-C mniejszego niż 100 mg/dl, mniejszego niż 130 mg/dl oraz mniejszego niż $145 \mathrm{mg} / \mathrm{dl}$, odpowiednio, u osób obciążonych bardzo wysokim ryzykiem sercowo-naczyniowym (z zalecanym LDL-C < $70 \mathrm{mg} / \mathrm{dl}$ ), wysokim ryzykiem sercowo-naczyniowym (z zalecanym LDL-C < $100 \mathrm{mg} / \mathrm{dl}$ ) oraz cechujących się średnim i niskim ryzykiem sercowo-naczyniowym (z zalecanym LDL-C $<115 \mathrm{mg} / \mathrm{dl}$ ).

\section{Podsumowanie}

W wytycznych z 2016 roku wyznaczono nie tylko nowe spojrzenie na lipidogram, ale także nowe potrzeby określania poszczególnych składowych lipidogramu i zaznaczania nowych norm i rekomendowanych wartości docelowych na wynikach otrzymywanych z medycznych laboratoriów diagnostycznych. Kardiolodzy zwracają uwagę, że w grupach bardzo wysokiego, wysokiego, umiarkowanego i niskiego ryzyka cel pierwszorzędowy wyrażony jako stężenie LDL-C określono, odpowiednio, jako:

- poniżej $70 \mathrm{mg} / \mathrm{dl}$ lub co najmniej 50\% przy wyjściowej wartości LDL-C 70-135 mg/dl;

- poniżej $100 \mathrm{mg} / \mathrm{dl} \mathrm{lub} \mathrm{co} \mathrm{najmniej} \mathrm{50 \%} \mathrm{przy} \mathrm{wyjściowej}$ wartości LDL-C 100-200 mg/dl;

- poniżej $115 \mathrm{mg} / \mathrm{dl}$;

- poniżej $115 \mathrm{mg} / \mathrm{dl}$.

Cel drugorzędowy, wyrażony jako stężenie nie-HDL-C, analogicznie wyznaczono jako:

- poniżej $100 \mathrm{mg} / \mathrm{dl}$;

- poniżej $130 \mathrm{mg} / \mathrm{dl}$;

- poniżej $145 \mathrm{mg} / \mathrm{dl}$;

- poniżej $145 \mathrm{mg} / \mathrm{dl}$.

Warto byłoby zatem, aby w medycznych laboratoriach diagnostycznych automatycznie wyliczano z myślą o kardiologach stężenia nie-HDL-C i podawano ich normy zgodnie z wytycznymi z 2016 roku. Jest to o tyle istotne, że w praktyce, zwłaszcza lekarza pierwszego kontaktu, warto brać pod uwage ważne, aczkolwiek proste przesłanie:

- stężenie LDL-C jako pierwszorzędowy cel leczenia służy w praktyce określeniu konieczności i rozważeniu rodzaju włączanej statyny; 
- stężenie nie-HDL-C jako drugorzędowy cel leczenia służy w praktyce określeniu, zwłaszcza u chorych z dyslipidemią aterogenną, cukrzycą, potrzeby zastosowania fibratu. To ważna konstatacja wobec wycofania się z określania w wytycznych docelowych wartości stężeń HDL-C i TG, które dotąd często służyły lekarzom praktykom do podjęcia decyzji o włączeniu fibratu.

Warto zauważyć, że lipidogram zazwyczaj rozpoczyna się od podania wartości TC, choć obecnie ma to przede wszystkim wartość historyczną, a sam wynik służy jako:

- bardzo wstępne określenie natężenia tego czynnika ryzyka;

- substrat do działania matematycznego (wyliczenia wartości nie-HDL-C);

- określenie ryzyka w skali SCORE (Systematic COronary Risk Evaluation), w której stężenie TC jest potrzebne na równi z wartością ciśnienia skurczowego, informacją o nałogu palenia tytoniu, wiekiem i płcią pacjenta do oszacowania jego ryzyka sercowo-naczyniowego w prewencji pierwotnej.

Dlatego w lipidogramie nadal powinny się znaleźć stężenia:

- TC;

- LDL-C;
- HDL-C;

- TG;

- nie-HDL-C.

Co prawda w wytycznych wyraźnie podkreślono, że przy obecnym stanie wiedzy nie istnieją docelowe wartości stężeń HDL-C ani TG, ale odnotowano, że wartości stężeń HDL powyżej 40 mg/dl u mężczyzn i wyższe niż 48 mg/dl u kobiet określają osoby z grupy niższego ryzyka, podobnie jak stężenie triglicerydów poniżej 150 mg/dl. Biorąc pod uwagę fakt, że nadal nie ustalono, czy istnieją graniczne, dolne wartości LDL-C, w przypadku których nie obserwuje się zjawiska obniżenia ryzyka sercowo-naczyniowego, określanie „dolnych norm” stężeń LDL-C w kontrolnym badaniu lipidogramu wydaje się zbyteczne, a w niektórych sytuacjach nawet szkodliwe.

W europejskich wytycznych dość wysoko oszacowano wartość predykcyjną stężeń ApoB (porównywalną do wartości predykcyjnej stężeń cholesterolu całkowitego lub wyliczanego nie-HDL-C), ale wydaje się, że z przyczyn ekonomicznych trudno będzie powszechnie wprowadzić to oznaczenie do polskich laboratoriów. Już teraz jednak można zażądać od współpracujących medycznych laboratoriów diagnostycznych czy wymóc na szpitalnych zakładach diagnostyki laboratoryjnej zupełnie nowy wzór

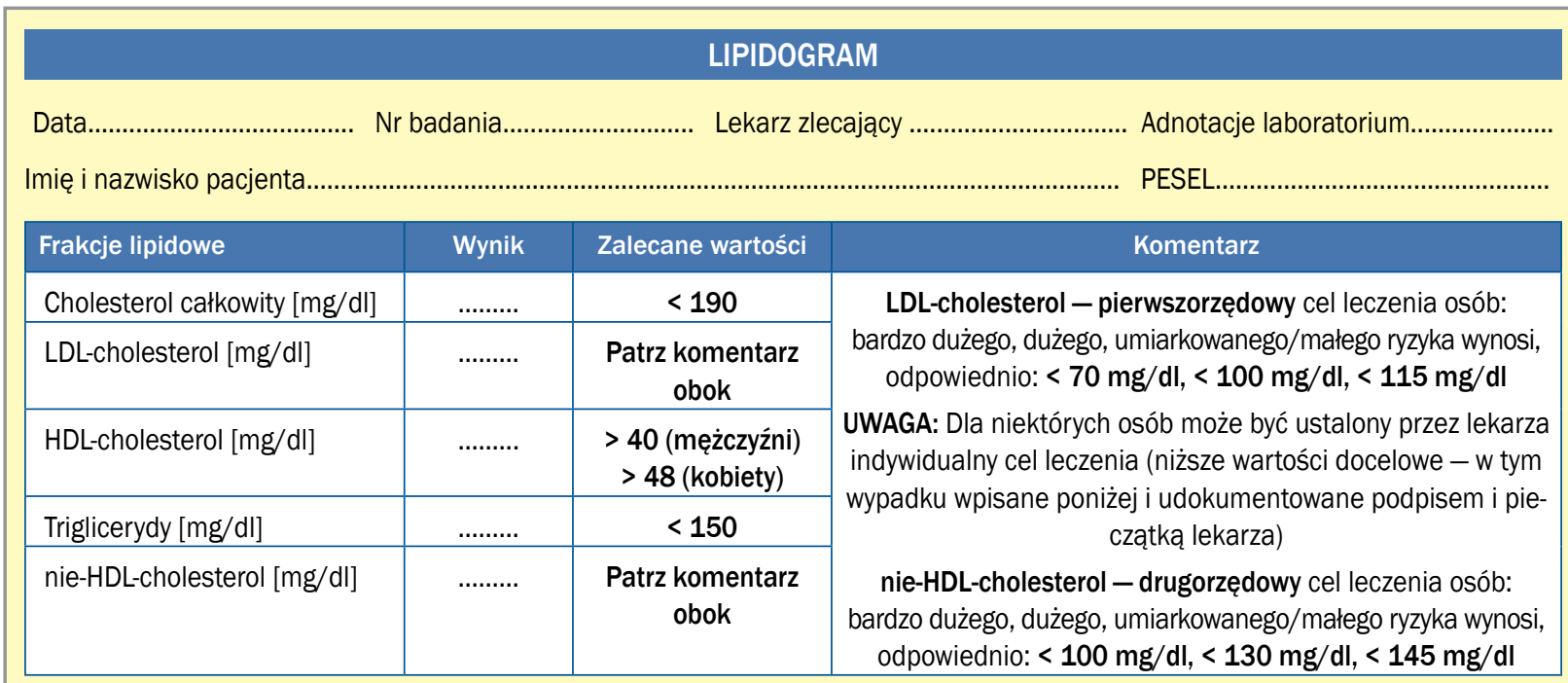

UWAGA: Prosimy o konsultacje wyniku lipidogramu z lekarzem kierującym

(podpis i pieczątka diagnosty laboratoryjnego)

Lekarz kierujący: Docelowe wartości LDL-cholesterolu określono na: $<\ldots . . . \mathrm{mg} / \mathrm{dl}$

(podpis i pieczątka lekarza)

Rycina 3. Autorska propozycja wyglądu wyniku lipidogramu, zgodna z wytycznymi Europejskiego Towarzystwa Kardiologicznego (ESC, European Society of Cardiology) dotyczącymi celów leczenia hipolipemizującego (zmodyfikowano na podstawie: [19]); HDL (high-density lipoprotein) - lipoproteiny o wysokiej gęstości; LDL (low-density lipoprotein) - lipoproteiny o niskiej gęstości 
wyniku lipidogramu, który mógłby wyglądać jak na rycinie 3 i spełniać omówione zmiany celów i hierarchii wartości poszczególnych frakcji lipidowych [19].

\section{Konflikt interesów}

Autorzy deklarują brak konfliktu interesów.

\section{Abstract}

The concentration of lipids and lipoproteins in plasma is essential in the treatment of lipid disorders. The routine lipid panel includes total cholesterol, triglycerides, cholesterol of low-density lipoprotein (LDL-C) and cholesterol of high-density lipoprotein (HDL-C). The latest guidelines of the European Society of Cardiology (valid until 2020) indicate that besides many players in the lipid arena (apolipoprotein, concentration and size of LDL particles) another parameter, non-HDL-cholesterol (non-HDL-C), is very important. This parameter, being easily available for routine clinical use, has been highlighted as a key secondary goal of therapy in patients with cardiometabolic risk.

Non-HDL-C is a superior parameter to LDL-C, especially the one estimated using Friedewald formula for prediction of cardiovascular events, because non-HDL-C is an integrated complex of all lipoprotein particles containing apolipoprotein B, i.e.: LDL, very low-density lipoproteins, intermediate-density lipoproteins, chylomicrons, remnants and Lp(a). Crucially, it can be calculated directly from the values of routine lipid panels, without additional cost.

In our opinion, non-HDL-C should be presented in all routine lipid profiles conducted by diagnostic laboratories. We also propose a new presentation of the results of routine lipid panel, which allows a significant change in treatment goals, taking into account the hierarchy of values of individual concentrations of lipoprotein fractions and how they are interpreted in the management of dyslipidaemia for optimal prevention of atherosclerosis and cardiovascular diseases.

Key words: non-HDL-C, LDL-C, routine lipid panel

Folia Cardiologica 2018; 13, 5: 435-441

\section{Piśmiennictwo}

1. Oliveira GBF, Avezum A, Roever L. Cardiovascular disease burden: evolving knowledge of risk factors in myocardial infarction and stroke through population-based research and perspectives in global prevention. Front Cardiovasc Med. 2015; 2: 1-32, doi: 10.3389/ /fcvm.2015.00032, indexed in Pubmed: 26664903.

2. Choi HY, Hafiane A, Schwertani A, et al. High-Density lipoproteins: biology, epidemiology, and clinical management. Can J Cardiol. 2017; 33(3): 325-333, doi: 10.1016/j.cjca.2016.09.012, indexed in Pubmed: 28063740.

3. Zdrojewski T, Jankowski P, Bandosz P, et al. Nowa wersja systemu oceny ryzyka sercowo-naczyniowego i tablic SCORE dla populacji Polski. Kardiol Pol. 2015; 73(10): 958-961, doi: 10.5603/kp.2015.0182.

4. Catapano A, Graham I, Backer GDe, et al. Wytyczne ESC/EAS dotyczące leczenia zaburzeń lipidowych w 2016 roku. Kardiol Pol. 2016; 74(11): 1234-1318, doi: 10.5603/kp.2016.0157.

5. Wożakowska-Kapłon B, Filipiak K, Mamcarz A, et al. Sekcja Farmakoterapii Sercowo-Naczyniowej Polskiego Towarzystwa Kardiologicznego. Aktualne problemy terapii dyslipidemii w Polsce - II Deklaracja Sopocka. Stanowisko grupy ekspertów wsparte przez Sekcję Farmakoterapii Sercowo-Naczyniowej Polskiego Towarzystwa Kardiologicznego. Kardiol Pol. 2014; 72(9): 847-853, doi: 10.5603/kp.2014.0182.

6. Wang GJ, Chang CT, Yang CY, et al. Negatively charged L5 as a naturally occurring atherogenic low-density lipoprotein. BioMedicine. 2012; 2(4): 147-154, doi: 10.1016/j.biomed.2012.05.003.
7. Stancel N, Chen CC, Ke LY, et al. Interplay between CRP, atherogenic LDL, and LOX-1 and its potential role in the pathogenesis of atherosclerosis. Clin Chem. 2016; 62(2): 320-327, doi: 10.1373/ /clinchem.2015.243923, indexed in Pubmed: 26607724.

8. Camont L, Chapman MJ, Kontush A. Biological activities of HDL subpopulations and their relevance to cardiovascular disease. Trends Mol Med. 2011; 17(10): 594-603, doi: 10.1016/j.molmed.2011.05.013, indexed in Pubmed: 21839683.

9. Libby P, Ridker P, Maseri A. Inflammation and atherosclerosis. Circulation. 2002; 105(9): 1135-1143, doi: 10.1161/hc0902.104353.

10. Sokolov AV, Kostevich VA, Runova OL, et al. Proatherogenic modification of LDL by surface-bound myeloperoxidase. Chem Phys Lipids. 2014; 180: 72-80, doi: 10.1016/j.chemphyslip.2014.02.006, indexed in Pubmed: 24631066.

11. Khera AV, Plutzky J. Management of low levels of high-density lipoprotein-cholesterol. Circulation. 2013; 128(1): 72-78, doi: 10.1161/

12. /CIRCULATIONAHA.112.000443, indexed in Pubmed: 23817482.

13. Sniderman AD, Toth PP, Thanassoulis G, et al. An evidence-based analysis of the National Lipid Association recommendations concerning non-HDL-C and apoB. J Clin Lipidol. 2016; 10(5): 1248-1258, doi: 10.1016/j.jacl.2016.07.008, indexed in Pubmed: 27678443.

14. Liao P, Zeng $R$, Zhao X, et al. Prognostic value of non-high-density lipoprotein cholesterol for mortality in patients with coronary heart 
disease: a systematic review and meta-analysis. Int J Cardiol. 2017; 227: 950-955, doi: 10.1016/j.ijcard.2016.10.106, indexed in Pubmed: 27939140.

15. Liu H, Deng X, Peng Y, et al. Meta-analysis of serum non-high-density lipoprotein cholesterol and risk of coronary heart disease in the general population. Clin Chim Acta. 2017; 471: 23-28, doi: 10.1016/j. cca.2017.05.006, indexed in Pubmed: 28495387.

16. Nordestgaard BG, Langsted A, Mora S, et al. European Atherosclerosis Society (EAS), European Federation of Clinical Chemistry and Laboratory Medicine (EFLM) Joint Consensus Initiative. Fasting is not routinely required for determination of a lipid profile: clinical and laboratory implications including flagging at desirable concentration cutpoints. Clin Chem. 2016; 62(7): 930-946, doi: 10.1373/clinchem.2016.258897, indexed in Pubmed: 27235445.

17. Nauck M, Warnick GR, Rifai N. Methods for measured of LDL-cholesterol: a critical assessment of direct measurement by homogenous assays versus calculation. Clin Chem. 2002; 48(2): 236-254, indexed in Pubmed: 11805004.

18. Sniderman A, McQueen M, Contois J, et al. Why is non-high-density lipoprotein cholesterol a better marker of the risk of vascular disease than low-density lipoprotein cholesterol? J Clin Lipidol. 2010; 4(3): 152-155, doi: 10.1016/j.jacl.2010.03.005, indexed in Pubmed: 21122647.

19. Roever L, Biondi-Zoccai G, Chagas AC. Non-HDL-C vs. LDL-C in predicting the severity of coronary atherosclerosis. Heart Lung Circ. 2016; 25(10): 953-954, doi: 10.1016/j.hlc.2016.06.790, indexed in Pubmed: 27432736.

20. Filipiak KJ. Atorwastatyna i rosuwastatyna - co nowego dla pacjentów w wytycznych Europejskiego Towarzystwa Kardiologicznego dotyczących dyslipidemii w 2016 roku? Statyny - które i w jakich dawkach? Spojrzenie eksperta z perspektywy początku 2017 roku. Kardiol Pol. 2017; 75(Suppl 1): 1-12, doi: 10.5603/KP.2017.0012. 